\title{
Social Networks Among Small-Scale Fishermen in Cilincing As a Strategy to Dealing With Uncertainty in Finding Fish Resources
}

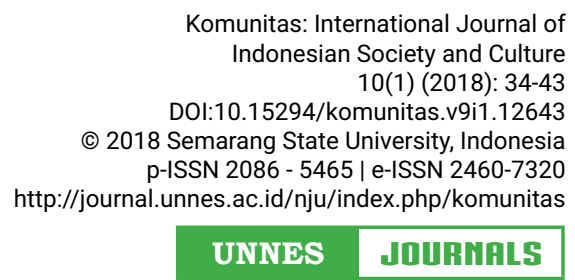

UNNES JOURNALS

\section{Dwiditya Pamungkas}

Social Welfare, Faculty of Social and Political Sciences, Univtersias Indonesia

Received: 1 January 2018; Accepted: 1 March 2018; Published: 30 March 2018

\begin{abstract}
This study discussed about utilization of social networks owned by Cilincing's small scale fishermen as strategy to facing uncertainty in the search of fish resources. The uncertainty conditions occurs due to environmental changes caused by the reclamation project of the bay of Jakarta and the disposal of waste derived from economic activities carried out in the coastal areas of North Jakarta. Uncertainty in the search for fish resources makes Cilincing's small scale fishermen have no fixed reguler income and that makes them very vulnerable to fall into poverty. this study used a qualitative approach by doing in-depth interviews and observations in the life of Cilincing's small scale fishermen. Based on the results of data collection, this study found that the forms of networks utilized by Cilincing's small scale fishermen is a network between individuals and network between individuals with institutions. They used those networks to obtain informations and access into resources they need to survive.
\end{abstract}

\section{Keywords}

uncertainty; poverty; social networks; information; access

\section{INTRODUCTION}

Indonesia is known as an archipelago country that has a rich diversity of natural resources (OECD, 2016). Indonesia is also known as an archipelagic country that has a vast territorial waters with abundant fish resources. An abundant fish resources become one source of livelihood for Indonesian coastal community. According to the Ministrial Decree of Maritime and Fisheries Affairs, No.47 / KEPMEN-KP / 2016, Indonesia has the potential of fish resources estimated at $9,357,811$ tons of fishes where those poten- tial is spread throughout the oceans in Indonesia. Of these potentials, the Ministry of Marine Affairs and Fisheries noted that Indonesia's fishery production in 2014 was only 6,484,346 tons (Ministry of Marine Affairs and Fisheries, 2015). If we comparing the fish production and the potential of fish resources in Indonesia, we can stated that

\footnotetext{
Corresponding author

$2^{\text {nd }}$ Floor, Nusantara II Building,

Fakultas IImu Sosial dan IImu Politik

Universitas Indonesia, Depok

Email

dwiditya@gmail.com
} 
Indonesia has not maximized the potential of fish resources

Ministry of Marine and Fisheries affairs noted that in 2012 the number of fishermen in Indonesia is about 2,748,908 inhabitants. The number decreased to $2,640,095$ in 2013. In 2014, the number of Indonesian fishermen increased again to $2,739,883$ people. The number of fishing vessels in 2014 is 212,979 units. Of these total, there are at least 153,493 units of fishing vessels with sizes below 5 Gross Ton. If referring to Law No. 45 of 2009 on fisheries, it can be said that most fishermen in Indonesia are classified as small fishermen with ship size below 5 Gross Ton. Semedi (2003) stated that the Indonesian fishing community is spread along 81, ooo kilometers in coastal areas.

Low socio-economic levels are a common feature of fishermen's life, especially small-scale and small scale fishermen (Kusnadi, 2002). The poverty trap that plagues small-scale fishermen lives is caused by complex factors. These factors are not only related to fluctuations in fish seasons, limited human resources, capital, access and trade networks of fish, but also due to the negative impact of fisheries modernization technologies that leads to excessive depletion of marine resources (see Kusnadi 2002: 26).

Characteristic of fishing activities in Indonesia continues to change and fishermen activities are not only based in rural areas, they also have fishing activities in urban areas (see Semedi, 2003). As we know, DKI Jakarta has coastal and marine areas located in North Jakarta and Kepulauan Seribu. This region is an area that has a community with a profession as a fisherman. According to Central Bureau of Statistics North Jakarta, there are at least 24 thousand fishermen located in Jakarta and they are scattered along the coast of North Jakarta.

Kusnadi (2002) argues that the conditions of poverty and socio-economic inequalities in the life of fishermen can be seen physically in the form of poor quality settlements. Poor fishing village will be easily identified from the condition of their residential house. And that condition is often found in the coastal areas of North Jakarta as in the areas of Kalibaru and Cilincing. Moreover, The level of poverty in North Jakarta is in the first position compared to other areas in Jakarta.

The challenge for small scale fishermen in the urban area is very different from the challenges faced by fishermen in the rural area. Not only the natural conditions like weather, but there are other aspects that are challenging fishermen in the urban area. Those aspects include fishery policy in the form of rules that must be adhered to related to fishing activities, reclamation project in Jakarta's coastal areas and environmental pollution that produced by factory waste and port waste that affect the availability of fish resources in the bay of Jakarta. These conditions makes the uncertainty of fish resources in the coastal area of Jakarta, and that uncertainty bringing small-scale fishermen life into a very vulnerable to poverty because there is no guaranteed of getting fish. In other words, fishermen have to cope with those dynamics changes that affect the living conditions of their economic and life systems (see Meltzof and Lipuma, 1986).

The polluted condition of Jakarta's northern sea has been making small-scale fisherman very difficult to do fishing activities to support their lives. The poor condition of the Jakarta's northern sea is caused by environmental pollution that comes from waste disposal of household and factory in Jakarta. Ministry of Environment and Forestry through Statistics Ministry of Environment and Forestry (SKLHK) in 2015 reported that the water clarity level in most ports in Indonesia has poor quality condition and from 1,133 coral reef locations in Indonesia only 5.30 percent which is in very good condition (Ministry of Environment, 2015). In addition, the existence of several reclamation islands that have been built also makes the condition of small-scale fishermen in sJakarta getting worse. During the process of building reclamation islands, fishermen began to lose their fishing ground so they were forced to go further to find another possible fishing grounds. They must have more financial capital if they 
want to seek a further fishing grounds.

In addition to the conditions discussed before, the government regulation No. 45 year 2009 about fisheries is also considered incriminating small-scale fishermen. Under that law, fishermen are governed in the possession of fishing gear. Through that law, fishermen only get one fishing permits based on their fishing gear. And for that, small fishermen can only have one fishing gear, but in the some circumstances, they must used more varied fishing gear for a different fish seasons. That condition makes small-scale fisherman in North Jakarta especially small scale fishermen usually violate that law when doing their fishing activities. Cilincing's small-scale fishermen do not just rely on their own fish catches to face some conditions previously discussed, they can do other strategies to survive. Related to this issue, this research is trying to find explanation about utilization of Cilincing's Small-scale social network to survive from uncertainty and poverty conditions.

The comprehensive explanation of social network utilization owned by a Cilincing's small-scale fisherman can be obtained if we understand the meaning of individuals and community groups in the facing problems they have in their lives. In this regard, the research approach used in this research is a qualitative approach, because this approach can be used to explore and understand the meaning (meaning) of an individual or group of people/societies that exist in a particular social problem (Creswell, 2014: 4). Neuman (2014) argues that qualitative approaches have the ability to construct social reality and cultural understanding so that by using this approach, it is expected to get illustration about Cilincing's small-scale life, social network and their challenges.

A more comprehensive perspective on the Cilincing's small-scale fishermen life can be deeply obtained in this study, because of the direct involvement of researchers in daily lives of them (see Rubin \& Babbie, 2011: 437). The data collection techniques used in this research are in-depth interviews and participant observation. The informants in- volved in this research are some Cilincing's small-scale fishermen and various informants that related to their lives.

\section{POVERTY OF CILINCING'S SMALL-SCALE FISHERMEN}

Referring to Kusnadi (2002), Cilincing's fishermen are classified as small-scale fishermen because they only have small scale technology and they only have capability catching the fish in the small-scale ways. Cilincing's small-scale fishermen do their fishing activities with full of speculation, and therefore the income of fishermen is uncertain and unpredictable, they were just like hunters and never have a prediction about the income they will get, all just speculation and uncertain (see Masyhuri, 2000: 9)

The Indonesia's government through regulation No. 45/2009 about fisheries sees fishermen as people whose livelihood is doing fishing activities and small fishermen are people using vessels with the size not more than 5 gross tons (GROSS TON). The description about small fishermen under the regulation No. 45 year 2009 is almost similar to the notion Kusnadi (2002) which states that small fishermen have only a small capital and have a small boat. Based on these explanations, small-scale fishermen of Cilincing are also seen as small fishermen.

The first general image can be seen from the conditions of poverty and socioeconomic disparities in the life of fishing communities are physical facts in the form the quality of their housing (Kusnadi, 2002). Poor fishing villages will be easily identified from the condition of their residential homes. Residential houses of small or smallscale fishermen are worse than those of modern fishermen (Kusnadi, 2002). Cilincing is known as the one district in North Jakarta with high population density and poor housing quality.

In addition to that general physical images, to identify the lives of poor fishermen can also be seen from the level of their children's education, the pattern of their daily life consumption and their le- 
vels of economy income (Kusnadi, 2002). The low of income caused to the low of their children's education. Besides that, the low children's education occurred because they have to stop their school and usually their children in the family must participate in helping families to earning a living (see Lwenya \& Yongo, 2012). In addition, the primary needs of the fishermen to keep survive and lived is just a food so that the needs of education and a decent home are not very important (see Kusnadi, 2002).

The condition of the fishermen is getting worse because they do not have other skills that can be used to work in other sectors, so that when the season not suitable to do fishing activities, the fishermen will become unemployed and usually they will only fixing their boat and fishing gear. Fishermen are deeply bound and depend on their life to be fishermen (see Kusnadi, 2002 and Semedi, 2003). Employment patterns as fishermen limits their activities to do work in another sectors, and thus affecting their income.

Small-scale fishermen not only facing poverty conditions as described above, they also facing their limitation role in local politics in their neighborhoods. That condition occurred because the small-scale fishermen spend lot of the time for searching and catching the fishes in the sea and when they have more time on land, they usually spend their time to take care of their family and improve or fixing their fishing equipment (see Acheson, 1981). These conditions can exacerbate the life of the fishermen, because they have no power in local politics. Eventually, the policies and forms of empowerment in the community usually do not considering the presence of fishing community.

\section{SURVIVING STRATEGY IN SMALL-SCALE FISHERMEN SO- CIETY}

Fishermen in their daily lives always face uncertainty in earning income (see Kusnadi, 2002). To face that condition, the fishermen do some strategies to survive. Fishermen's strategy is certainly different from the farmer's strategy (see Kusnadi, 2002). Kasperski \& Holland (2013) argue that in increasing revenue and facing the uncertainty of the catch, fishermen tend to increase the catchment zone and improve the quality of their fishing gear technology. Kasperski \& Holland (2013) opinions is more suitable if applied to view modern fisherman's strategy.

The strategy of small-scale fishermen is more different in any circumstances with modern fishermen. When they have no income, usually the wives and children of fishermen have to struggle to participate in making a living by doing all the work (see Kusnadi, 2009: 5). However, the availability of jobs that can be taken is depends on the capabilities needed and owned by the fishermen and their family.

Fishermen also creatively create smallscale institutions, such as religion, arisan, saving and loans group (Kusnadi, 2002: 36). According to Kusnadi (2002), these institutions have a dual function of strengross tonhening social relations and helping to overcome the uncertainty of economic income. Kusnadi (2002) also emphasized that the strategy can be done by fishermen in facing uncertainty is doing diversify. By diversifying the work, it is expected that the sources of fishermen's income will be more diverse and their access to economic resources will be wider and more flexible (Kusnadi, 2002: 47). In addition, to fulfill their daily needs, small-scale fishermen usually owe money to the others (see Abraham, 1985). In fact, debt is not the main solution in the effort to meet their daily needs. According to Acciaioli (2000), indebted fishermen actually enter into the poverty trap because they will use their next income to pay off their previous debts.

Performing various forms of strategy certainly involves the others. For example, diversifying jobs to other sectors certainly requires relationships with the people who can provide a jobs. Sudrajat (2016) argues that one of the strategies that can be done by fishermen is to build social relationships with the others. According to that, the use 
of relations and social networks can be seen as a survival strategies of small scale fishermen.

\section{THE FORMS OF SOCIAL NET- WORKS OF CILINCING'S SMALL- SCALE FISHERMEN}

Every human being needs to interact and maintain social relationships with other human beings (see Agusyanto, 2010:31). According to Agusyanto (2007), social relations can be seen as a path or channel connecting one person to another through which the channel or channel can be transferred something such as goods, services or information (Agusyanto, 2007:14). Fischer in Putnam (2000) states that social networks are important in our lives, can be used to find work and seek for help.

The social relationships in which each individual meets can be seen as a form of social network (Boissevain, 1974). This social network in the abstract level is seen as the spreading point connected by the lines. The point is a human and connecting lines are social relations (Boissevain, 1974: 24). According to Boissevain (1974), the social network is more than a communications network, this network is in the form of transactions. The transcation referred by Boissevain (1974) is the interaction between actors formed on the basis of the principles of obtaining equivalent or more value exchanges.

Lawang (2005) explains that the network can be formed into several networks which is inter-personal networks, networks between individuals and institutions and networks between institutions. The network is always formed in interpersonal (Lawang, 2005: 63). Interpersonal networks are formed when there is an interest in the network, not just ordinary conversations. In such relationships, the flow of actorsrelations is usually viewed on the basis of the content and intensity of their relationship which means that each actor has different access to a resource or network (Shubin, 2007)
Networks owned by small scale fishermen in Cilincing do not necessarily form by themselves. The first way that can be done by small scale fishermen to be able to open their network is by associating their selves with the other people around them. Lawang (2005) stated that the most powerful media in opening the network is the association in the general sense by opening up.

Networks that have been formed can be seen into several shapes and types. Refers to Agusyanto (2014), viewed from the purpose of social relationships that formed social networks that exist in society, the network can be divided into three types: interest networks, emotional networks and power networks. Each network owned by Cilincing's small-scale fishermen can be classified into one of these types according to the particular context or situation.

The interests networks is formed on the basis of meaningful social relations on the particular or specific goals the perpetrators are interested in (Agusyanto, 2010: 76). Goals to be achieved are usually related to the effort to obtain resources and services. If the goal has been achieved, the relationship usually does not last long. However, if there is an effort to continually have an interest in obtaining resources, then this network will survive. In the case of Cilincing's small-scale fishermen, the interests network can be seen in every relationship or networks that they have with their fellow small-scale fishermen. The interest to be achieved by fishermen through this network is to obtain fish resources and other livelihood sources. For example, when the key informants in this research do not have the financial capital to go fishing in the sea, they will use their network with other fishermen to go fishing. Conversely, when they are having difficulty finding a fishing crew, usually they used their networks to find a fishermen who want to become their crew. In that conditions, there is a flowing transaction as described by Boissevain (1974).

In the emotional networks, the networks is formed on social relationships in which social relations itself becomes the goal of social action such as in friend- 
ship, romance or/and relative relationships (Agusyanto, 2014). Emotional ties among small-scale Cilincing fishermen are formed from all the problems they face together. The strengross tonh of this bond eventually formed a network that led to the formation of joint ventures and fishermen's community group in Cilincing. This emotional network can be used and manipulated to achieve desired interests (see Agusynato 2014).

Configuration of interconnectedness between intentional actors or regulated relation is one of the characteristics of power networks. This type of social network arises when the achievement of targeted objectives requires collective action and interconnection between actors is usually made permanent (see Agusyanto, 2014: 31). In the case of the Cilincing's small-scale fishermen, this power networks seen when Cilincing's small-scale fishermen including the three informants in this study wanted to achieve their common goals such as getting social assistance and social insurance from the government. The power network of small-scale fishermen is activated through cooperatives and associations to reach related government institutions in the fisheries. In this study, a very visible and strong type of the networks found is the emotional network that is always used to achieve the desired goals by fishermen. The social networks of Cilincing's small-scale fishermen tend to be formed due to emotional relationship based on friendship, fraternity, and the sense of belonging.

In this study reveal that the form of Cilincing's small-scale networks is the interpersonal network with the emotional based on the relationships between individuals that representing their each personal interests. In addition to the form of interpersonal network, the form of network between individuals and institutions can also be seen in the Cilincing's small-scale fishermen networks. The form of inter-personal network with institutions was found when they make relations with the Cilincing's fish auction (TPI) as representative of Sub-dept. Of Marine, Agriculture and Food Security in North Jakarta (KPKP). Although the social networks they formed with Cilincing's fish auction (TPI) are represented by individuals, but the individuals representing the government has a power and considered as institutional representatives. For example, one of the key informants in this study used its networks with Cilincing's fish auction (TPI) to obtain and manage their fishery permits and to gain access to the social assistance and social insurance from the government.

\section{UTILIZATION OF SOCIAL NET- WORK FOR CILINCING'S SMALL- SCALE FISHERMEN}

The networks formed by Cilincing's fishermen is not simply a relationship that only produces a friendship or just know each other. It called as a network because there is flow of transactions of any resources in that connection (see Agusyanto, 2014). This study show that all the networks they own used to find resources. Under these conditions, the use of networks owned by the informants in this study is in line with the opinion of Boissevain (1974) which states that social networks are more than ordinary communications networks, these networks are in the form of transactions. The transcation referred to by Boissevain (1974) is the interaction between actors formed on the basis of the principles of obtaining equivalent or more value exchanges.

The existence of networks utilization owned by Cilincing's small-scale fishermen has shown that the networks has several functions. According to Lawang (2005), informative function is also called information media or information network that allows each person in the network can find information related to their problem, or opportunities or anything related to their business activities. This informative function can be seen as a function of opportunity, because every opportunity can be obtained with the networks (see Lawang, 2005: 69). Informative function is very visible when the Cilincing's small-scale fishermen in this research utilize their network to find information about fishing grounds, information 
about fishery markets, information about aid from the others and information about all fishery regulations.

An informative function enables a person within the networks to gain informations and opportunities. Not just offering informations, that networks also has a function access. Lawang (2005) explains that the access function refers to opportunities that can be provided by the networks with others in the provision of goods or services that can not be fulfilled internally within the organization (Ostgaard and Birley in Lawang, 2005). By having a network, all informants in this study can seek access to fish resources they need. As one example, Cilincing's small-scale fishermen sought and bought fish from fishermen they knew outside Jakarta area, and then they sold that fish in Jakarta with a slightly higher price. In addition to accessing fish resources, they can also access government social assistance through their networks with cooperatives and local government institutions such as Cilincing's fish auction (TPI). When the units within the network or Cilincing's small-scale fishermen in this study can open access to government or other institutions and they can obtain a resource from that institutions networks, and for that, they have received a coordination function within the networks.

Having a networks can help and facilitate Cilincing's small-scale fishermen in finding solutions and solving fisheries problems they face in their daily life. That explanation in line with the opinion from Boissevain (1974) which states that the function of the networks has been able to provide help to the fishermen in solving the problems encountered. It is also in line with Fischer's opinion in Putnam (2000) which states that social networks are important in our lives, can be used to seek work and seek help.

\section{SOCIAL NETWORKS AS SOCIAL CAPITAL}

Putnam (2000) argues that the networks can provide benefits for human life. That opinion is seen in the life of Cilincing's small-scale fishermen who became informants in this study. They thought the networks they have has provided ease in facing the challenges of being a fisherman. The networks owned by Cilincing's small-scale fishermen can be seen as a social capital. Lawang (2005) explains that social networks is the core of social capital itself. The networks itself provides one's ability to survive and improve standard of living. According to Putnam (2000), the networks provides social contacts that can affect the productivity of individuals or groups. From the point of view of social capital, the networks can be seen in three forms of social capital which is bonding, bridging and linking. In this study, the Cilincing's small-scale fishermen networks found will be discussed as social capital in the form of bonding, bridging and linking.

Hawkins and Maurer (2010) distinguish social capital in three types: bonding bridging and linking. Bonding social capital refers to the relationship in which members within the network share similarities in some form such as ethnic and other similarities, in other words, this relationship is more homogeneous (see Putnam, 200o). Szreter and Woolcock (2004) argues that in bridging social capital, the relationships are formed among people who have differences such as age, socioeconomic status, race, education and ethnicity. In other words, the nature of bridging social capital is more varied and heteorgen compared to bonding social capital. Linking social capital is a broader relationship because the relationships built by individuals connected to the institutions or individuals who have power and representing the institutions. In other words, the ability to gain access to institutions can also able to help person in getting help or work.

As mentioned before, bonding social capital is a networks between individuals who have similarities or more homogeneous. In this study, bonding social capital is found in networks formed by fishermen with fellow fishermen residing in the same region or having the same type of fishing gear. In this research, all of the informants has a network with a small crab fisherman, From each of each networks in the form of bonding social capital can lead to the for- 
ming group of joint ventures (KUB).

Called as bonding because they connected and networked with fellow fishermens who have similarities in the form of similar types of fishing gear and have a residence located in the same region. In addition to that similarity, usually the background of tribes and the family system owned by fishermen also strengross tonhen the formation of networks among fishermen and bonding in social capital. This form of bonding can be seen as a networks formed on the basis of emotional bonding as explained by Agusyanto (2014) and is a networks in the form of inter-personal as proposed by Lawang (2005).

Bonding among Cilincing's small-scale fishermen is a networks that is very visible in the life cycle of fishermen when they able to do fishing activities or when they can't able to do fishing activities. In the cycle of fishing, Bonding is seen when fishermen are preparing for fishing activities, when fishing operation and post-fishing operation. Preparing phase of fishing activities is the most important phase in the life cycle of Cilincing's small-scale fishermen. In that phase, bonding social capital becomes the most important thing because through that bonding they can get all the information about fish resources so they can face uncertainty condition. Beside that, through that bonding, they can also do business together with the other fisehrmen.

In bridging social capital a relationship among Cilincing's small-scale fishermen is formed more broadly than bonding social capital because in this bridging relationship, connected individuals have different and diverse backgrounds. In this study, in addition to having a networks with fishermen who have similarities, the informants also build their networks with other fishermen who have different backgrounds referring to differences in the use of fishing gear, the difference of residence and ethnic or tribal differences. That networks also built connection among informants with fishermen outside the Jakarta area. In the case of this study, it was found that the all of the informants not only networked with fisher- men who had the same background, they also had a wider networks and that network was manifested in the Kalibaru, Cilincing and Marunda fishermen community group (paguyuban KCM) they owned. By having these bridging social capital, the fishermen have a greater chance to look for opportunities in their survival efforts.

Bridging social capital seen in the life cycle of Cilincing's small-scale fishermen when they able or not to do fishing activities. The bridging function is seen when smallscale Cilincing fishermen need information as well as human and fish resources coming from outside of Cilincing area. Bridging social capital has made it easy for small-scale Cilincing fishermen to access resources from outside the Cilincing area.

In addition to networking with fishermen who have the same background or with fishermen who have different backgrounds, Cilincing's small-scale fishermen in this study also has a networks with the other who have the power or represent related institutions. Inter-personal networks with institutions built by small-scale Cilincing fishermen seen as a form of linking social capital.

Linking social capital of Cilincing's small-scale fishermen with the government is very visible when the small-scale fishermen are in the cycle not able to do fishing activities. In that cycle, information about fisheries regulations, social assistances, social insurances and access to all of that can be obtained by utilizing linking social capital owned by Cilincing's small-scale fishermen. Besides that, linking also has a function when the fisherman is in the preparation phase of fishing activities. In that phase, linking is used to obtain information about the current regulation fishery.

\section{CONCLUSION}

The ability to understand networks within a community can help social practitioners to explain people's lives in dealing with problems in their life. In this study, it was found that the main problem faced by Cilincing's small-scale fishermen is uncertainty in finding and obtaining fish resources. To deal 
with these conditions, they take advantage of the various social networks they have. The form of networks in the life of Cilincing's small-scale fishermen is a networks between personal and networks between individuals with institutions. That networks seen as social capital of fishermen in the form of bonding, bridging and linking. Bonding social capital is very important in the life of Cilincing's small-scale fishermen, they used their bonding social capital to be able to deal with uncertainty and poverty conditions.

Bonding is the most important social capital among other forms because this social capital is in the first layer or the first networks used by Cilincing's small-scale fishermen to be able to deal with all conditions of uncertainty in the search for fish resources. Through bonding, Cilincing's small-scale fishermen can get information about fishery regulations, fish resource information, information about social assistance from government and can do business together and get jobs from the other.

\section{REFERENCES}

Acheson, J.M., 1981. Anthropology of Fishing. Annual Review of Anthropology. (10), pp. 275-316.

Acciaioli, G., 200o. Kinship and debt: The social organization of Bugis migration and fish marketing at Lake Lindu, Central Sulawesi. bijdragen tot de Taal-, Land-en Volkenkunde, 156(3). pp. 589-617.

Abraham, A., 1985. Subsistence Credit: Survival Strategies among Small-scale Fishermen. Economic and Political Weekly, 20 (6), pp. 247-252.

Agusyanto, R., 2007. Jaringan Sosial dalam Organisasi. Raja Grafindo Persada, Jakarta.

Agusyanto, R.., 2010. Fenomena Dunia Mengecil. Institut Antropologi Indonesia, Jakarta.

Amato, P.R. dan Jiping Z., 1992. Rural Poverty, Urban Poverty, and Psychological Well-Being. The Sociological Quarterly, 33(2), Pp. 229-240.

Ardales, V.B. dan Fely P. D., 1985. Poverty Among Small-Scale Fisehrmen in Iloilo. Philippine Sociological Review, 33(1/2), Pp. 35-39.

Boissevain, J., 1978. Friends of friends, Network, Manipulators and Coalitions. Blackwell, Oxford.

Creswell, J. W., 2014. Research Design: Qualitative \& Quantitative Approaches. SAGE Publications, California.Creswell J.W. \& Plano C.V.L., 2011 Designing and conducting mixed method research. 2nd edition. Sage Thousand Oaks, California.

Imron, M., 2003. Kemiskinan dalam Masyarakat Ne- layan. Jurnal Masyarakat dan Budaya, 5(1), pp. 63-81.

Irving, H., 1977. Social Networks in the Modern City. Social Forces, 55(4), pp. 867-88o.

Kasperski, S. dan Daniel S. H., 2013. Income diversification and risk for fishermen. Proceedings of the National Academy of Sciences of the United States of America, 110(6), pp. 2076-2081.

Kusnadi, 2002. Konflik Sosial Nelayan: Kemiskinan dan Perebutan Sumber Daya Perikanan. LKIS, Yogyakarta.Mashyuri dan Mochammad N., 20oo. Pemberdayaan Nelayan Tertinggal: Sebuah Uji Model Penanganan Kemiskinan. Puslitbang Ekonomi dan Pembangunan-LIPI, Jakarta.Martin, S.M., Kai L. dan Nil B., 2013. Fishing Farmers: Fishing, Livelihood Diversification and Poverty in Rural Laos. Human Ecology, 41(5), pp. 737-747.

Meltzoff, S.K. dan Edward L., 1986. The Troubled Seas of Spanish Fishermen: Marine Policy and the Economy of Change. American Ethnologist, 13(4), pp. 681-699.

Mitchell, C.J., 1974. Social Networks. Annual Review of Anthropology, (3), pp. 279-299.

Mukul, 1993. Small-scale Fisher-People against Fishing Harbour. Economic and Political Weekly, 28(38), pp. 1974-1975.

Mowafi, M dan M. Khawaja, 2005. Poverty. Journal of Epidemology and Community Health, 59(4), pp. 260-264.

Myers, B., 200o. Walking With The Poor. World Vision International, Monrovia.

Naraya, Deepa, Patel, Raj Schafft, 200o. Voices of the poor : can anyone hear us? Oxford University Press, New York.Pi-Sunyer, O., 1987. Fishermen and Peaseants. American Ethnologist, 14(2), p. 377.

Putnam, R.D., 200o. Bowling alone: the collapse and revival of American community. Simon \& Schuster, New York.

Robben, A.C.G.M., 1982. Stratification, Scale, and Ranking: Social Change in Two Brazilian Fishing Communities. Ethnology, 21(2), pp. 125-135.

Robben, A.C.G.M., 1994. Conflicting Discourses of Economy And Society in Coastal Brazil. MAN, New Series, 29(4), pp. 875-90o.

Schachner, G., 2012. Social Interaction Networks. In Population Circulation and the Transformation of Ancient Zuni Communities. University of Arizona Press

Semedi, P. 2003.Close to The Stone, Far From te the Throne. Benang Merah, Yogyakarta.

Shubin, S., 2007. Networked Poverty in Rural Russia. Europe-Asia Studies, 59(4), pp. 591-620.

Spradley, J.P., 1979. The ethnographic interview. Holt, Rinehart \& Winston, New York.

Suparlan, P., 1984. Kemiskinan di Perkotaan. Yayasan Obor Indonesia, Jakarta.

Sudrajat, J., 2016. Livelihood Strategy of Coastal Community: A Case Study in Tanjung Saleh Islands, Kubu Raya District, Indonesia. Komunitas, 8(1), pp. 22-31. 
Suharto, E., 2005. Membangun masyarakat, memberdayakan rakyat: kajian strategis pembangunan kesejahteraan sosial dan pekerjaan sosial. Refika Aditama, Bandung.

Szreter, S. and Woolcock, M., 2004. Health by association? Social capital, social theory, and the political economy of public health. International Journal of Epidemology, 33(4), pp. 650-670.

Vogross ton, W. P., 1999. Dictionary of Statistics and Methodology: A Nontechnical Guide for the Social Sciences. Sage, London.Walton, J., 1986. Dimensions of Poverty in Southeast Asia. Southeast Asian Journal of Social Science, 14(1), pp. 1-15.
Wekke, I.S. dan Andi C., 2015. Fishermen Poverty and Survival Strategy: Research on Poor Households in Bone Indonesia. Procedia Economics and Finance (26), pp. 7 - 11.

West, D.A., 1970. The Relationship Between Rural and Urban Poverty. Proceeding, Annual Meeting Proceedings, 43, Pp. 203-209.

Wilson, W.J. dan Robert A.., 1985. Urban Poverty. Annual Review of Sociology, (11), pp. 231-258.

Woolcock, M. 2001. The place of social capital in understanding social and economic outcomes. Canadian Journal of Policy Research, 2(1), pp. 11-17. 